Article

\title{
Pachydictyols B and C: New Diterpenes from Dictyota dichotoma Hudson
}

\section{Ghada S. E. Abou-El-Wafa ${ }^{1, \dagger}$, Mohamed Shaaban ${ }^{2,3, \dagger, *}$, Khaled A. Shaaban ${ }^{2, \dagger}$,} Mohamed E. E. El-Naggar ${ }^{1 \ddagger}$, Armin Maier ${ }^{4}$, Heinz H. Fiebig ${ }^{4}$ and Hartmut Laatsch ${ }^{2}$

1 Department of Botany, Faculty of Science, Mansoura University, Algomhuria St. 60, El-Mansoura 35516, Egypt; E-Mail: dodymarine99@yahoo.com

2 Institute of Organic and Biomolecular Chemistry, University of Göttingen, Tammannstrasse 2, D-37077 Göttingen, Germany; E-Mails: kelbarbary100@yahoo.com (K.A.S.); hlaatsc@gwdg.de (H.L.)

3 Chemistry of Natural Compounds Department, Division of Pharmaceutical Industries, National Research Centre, El-Behoos St. 33, Dokki-Cairo 12622, Egypt

4 Oncotest GmbH, Am Flughafen 12-14, D-79108 Freiburg, Germany; E-Mails: armin.maier@oncotest.de (A.M.); heiner.fiebig@oncotest.de (H.H.F.)

$\dagger$ These authors contributed equally to this work.

* Deceased on 9 December 2011.

* Author to whom correspondence should be addressed; E-Mail: mshaaba_99@yahoo.com; Tel.: +202-270-1728 (ext. 2609); Fax: +202-3337-0931.

Received: 19 June 2013; in revised form: 12 August 2013 / Accepted: 12 August 2013 / Published: 22 August 2013

\begin{abstract}
Two new diterpenoids, pachydictyol B (1a/1b) and C (2), were isolated from the dichloromethane extract of the marine brown alga, Dictyota dichotoma, collected from the Red Sea coast of Egypt, along with the known metabolites, pachydictyol A (3a), dictyol E (4), cis-africanan-1 $\alpha$-ol (5a), fucosterol (6), tetrahydrothiophen-1,1-dioxide and poly- $\beta$-hydroxybutyric acid. GC-MS analysis of the nonpolar fractions also indicated the presence of $\beta$-bourbonene and nonanal, along with three hydrocarbons and five fatty acids or their simple derivatives, respectively. GC-MS analysis of the unsaponifiable algal petroleum ether extract revealed the presence of a further eight compounds, among them 2,2,6,7-tetramethyl-10-oxatricyclo[4.3.0.1(1,7)]decan-5-one (7), $N$-(4-bromo- $n$-butyl)-pipe ridin-2-one (8) and tert-hexadecanethiol. Structures 1-6 were assigned by 1D and 2D NMR, mass spectra (EI, CI, HREI and HRESI) and by comparison with data from related
\end{abstract}


structures. The crude algal extract was potently active against the breast carcinoma tumor cell line, MCF7 ( $\mathrm{IC}_{50}=0.6 \mu \mathrm{g} \mathrm{mL}^{-1}$ ); pachydictyol B (1a) and dictyol E (4) showed weak antimicrobial properties, and the other compounds were inactive. Pachydictyols B (1a) and $\mathrm{C}$ (2) demonstrated a weak and unselective cytotoxicity against twelve human tumor cell lines with a mean $\mathrm{IC}_{50}$ of $>30.0 \mu \mathrm{M}$.

Keywords: marine brown alga; Dictyota dichotoma; pachydictyols; diterpenes; bioactivity

\begin{abstract}
Abbreviations
AM1: Austin Model 1 (a model used in quantum physics); CI MS: Chemical Ionization Mass Spectra/Mass Spectrometry; COSY: Correlation Spectroscopy; DCI MS: Desorption Chemical Ionization; EI MS: Electron Impact Mass Spectra/Mass Spectrometry; GC-MS analysis: Gas Chromatographic-Mass Spectrometric analysis; HMBC: Heteronuclear Multiple-Bond Correlation; HMQC: Heteronuclear Multiple-Quantum Correlation; HREI MS: High Resolution Electron Impact Mass Spectra/Mass Spectrometry; HRESI MS: High Resolution Electrospray Mass Spectra/Mass Spectrometry; HSQC: Heteronuclear Single Quantum Correlation; NMR: Nuclear Magnetic Resonance; NOE: Nuclear Overhauser Effect; NOESY: Nuclear Overhauser Effect Spectroscopy; PTLC: Preparative Thin-layer Chromatography; TLC: Thin Layer Chromatography.
\end{abstract}

\title{
1. Introduction
}

Brown algae belonging to the family, Dictyotaceae, are a rich source of biologically active isoprenoids [1,2]. About 200 diterpenoids, belonging to 15 chemical classes, have been isolated from Dictyota spp. [3-5]. Some of these compounds are reported to display significant cytotoxic, antiviral, feeding-deterrent and antifouling activities [3,6-10] or were useful for chemotaxonomic and biogenic studies of the genus, Dictyota [11,12]. The production of secondary metabolites in other genera of benthic marine brown algae has also been reported and is often associated with protection against herbivores [13].

During our search for bioactive diterpenoids from marine sources, the brown alga, Dictyota dichotoma (Hudson) Lamouroux, from the Red Sea, was selected for further investigation on the basis of notable in vitro cytotoxicity of a crude extract against the breast carcinoma tumor cell line, MCF7 $\left(\mathrm{IC}_{50}=0.6 \mu \mathrm{g} \mathrm{mL}{ }^{-1}\right)$ and on the basis of chemical screening by TLC. Several UV-inactive bands ranging from low to high polarity were detected that turned pink or gave a blue-violet color after spraying with anisaldehyde/sulfuric acid, suggesting the presence of isoprenoids. Soxhlet extraction of the algae using dichloromethane, followed by a series of chromatographic steps, afforded three new diterpenes, cis- and trans-pachydictyol B (1a/1b) and pachydictyol C (2), see Figure 1. Additionally, the known metabolites, pachydictyol A (3a) [3], dictyol E (4) [14,15], cis-africanan-1 $\alpha$-ol (5a) [16], fucosterol (6), poly- $\beta$-hydroxybutyric acid and tetrahydrothiophene-1,1-dioxide, were isolated. GC-MS analyses of the nonpolar fraction and of the unsaponifiable residue of the algal extract revealed 18 further components, among them 7-9 (Supplementary Material, Tables S1 and S2). 
Figure 1. Structures of compounds 1-9.

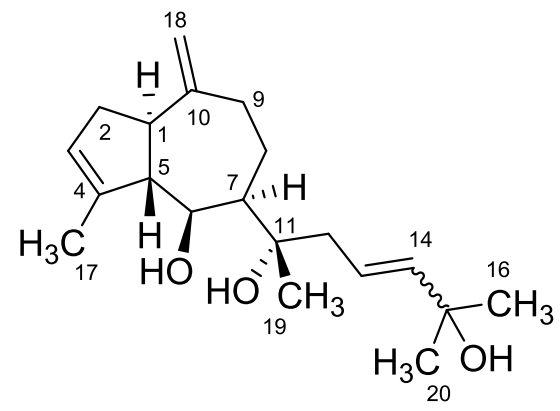

1a: $\left(Z-\Delta^{13}\right)$; 1b: $\left(E-\Delta^{13}\right)$

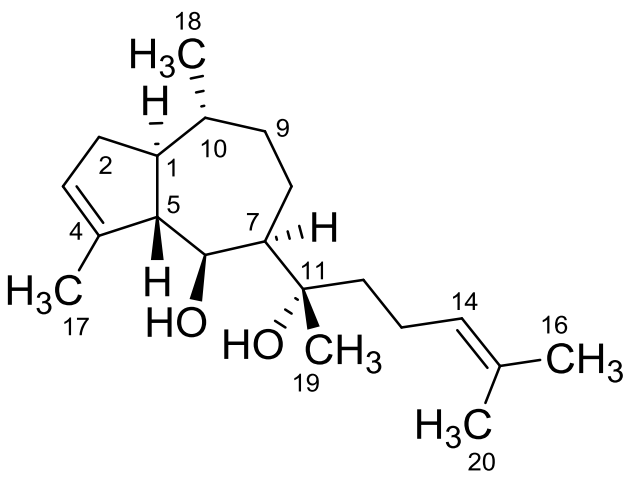

2

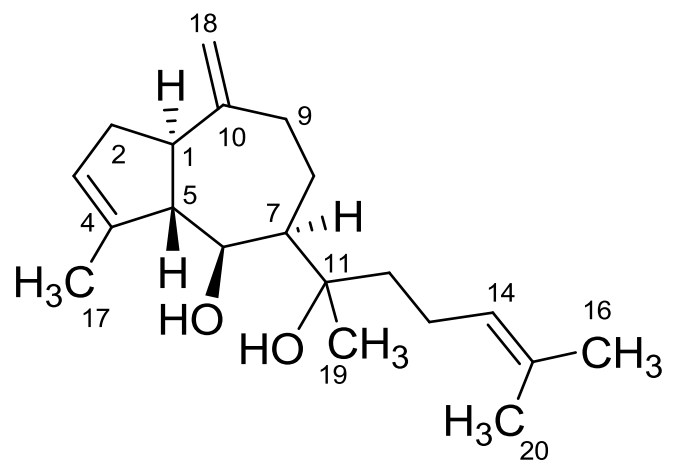

4

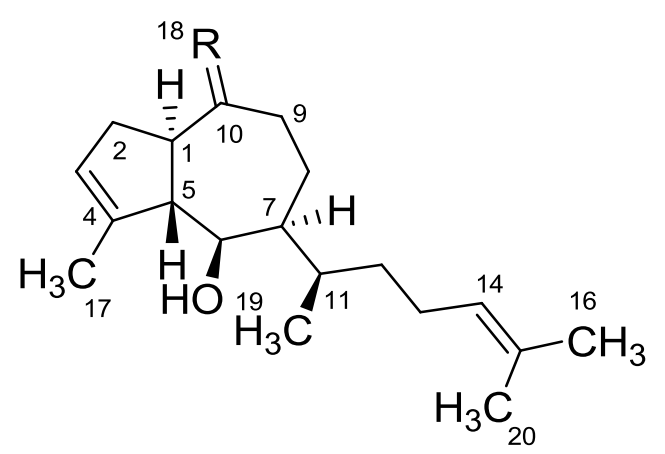

3a: $\mathrm{R}=\mathrm{CH}_{2} ; \mathbf{3 b}: \mathrm{R}=\alpha-\mathrm{CH}_{3}, \beta-\mathrm{OH}$

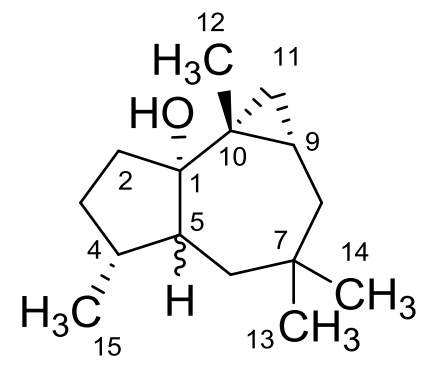<smiles>CC1(C)CCC(=O)C2(C)C(C)(C)CCC12O</smiles><smiles>O=C1CCCCN1CCCCBr</smiles>

8<smiles>CCC(C)CC(C)(CC)CC(C)(C)S</smiles>

9 


\section{Results and Discussion}

\subsection{Structure Analysis and Characterization of Isolated Compounds}

Separation of $D$. dichotoma extracts on silica gel delivered eight compounds with a wide range of polarities. Under TLC monitoring, four compounds of moderate to high polarity were especially conspicuous. They were not UV absorbing, but stained intensely violet when sprayed with anisaldehyde/sulfuric acid. The least polar compound and a moderately polar component were identified as pachydictyol A (3a) [3] and dictyol E (4) [14,15], respectively, by means of NMR and MS data. The other two compounds showed a close similarity to $\mathbf{3 a}$ and $\mathbf{4}$ and appeared to be new derivatives thereof.

Compound 1a was obtained as polar colorless oil, with a molecular weight of $\mathrm{m} / z 320$ Dalton by DCI MS. EI MS showed two characteristic fragment ions resulting from the successive loss of two molecules of water. (+)-HRESI MS confirmed the molecular formula as $\mathrm{C}_{20} \mathrm{H}_{32} \mathrm{O}_{3}$, with the same number of double bond equivalents as in $\mathbf{3 a}$, but with two more oxygen atoms.

The ${ }^{13} \mathrm{C}$ NMR/HMQC spectra of 1a confirmed the expected twenty carbon signals and pointed to a close structural similarity with $\mathbf{3 a}$ and $\mathbf{4}$. The olefinic carbons of $\mathbf{1 a}$ had nearly the same shifts as for 3a/4; however, they were assigned by HSQC to three olefinic methines, two $\mathrm{sp}^{2} \mathrm{C}_{\mathrm{q}}$ atoms and one exocyclic methylene group $(3 / 2 / 1)$ instead of $2 / 3 / 1$, as in $\mathbf{3 a} / \mathbf{4}$. Between $\delta_{\mathrm{C}} 70 \sim 76$, there were three signals from oxygenated carbons visible in the spectrum of 1a, but only one for $\mathbf{3 a}$ and two for $\mathbf{4}$, respectively. This indicated a new dihydroxypachydictyol A, that we named pachydictyol B (1a).

An intensive spectroscopic study of compound 1a revealed the same octahydroazulen-4-ol parent structure substituted at the 7-position as found in pachydictyol A (3a) and dictyol E (4) (Tables 1 and 2). The $\mathrm{sp}^{2}$ methylene protons $\mathrm{H}_{2}-18$ displayed $\mathrm{HMBC}$ correlations with the quaternary carbon $\mathrm{C}-10\left(\delta_{\mathrm{C}}\right.$ 151.6, $\left.{ }^{2} J\right)$ and its neighboring methine $\mathrm{CH}-1\left(\delta_{\mathrm{C}} 46.0,{ }^{3} J\right)$ and methylene $\mathrm{CH}_{2}-9\left(\delta_{\mathrm{C}} 40.3\right)$ carbons. The angular methine proton at $\mathrm{C}-1\left(\delta_{\mathrm{H}} 2.50\right)$ showed three HMBC correlations, with the methine carbon $\mathrm{CH}-5\left(\delta_{\mathrm{C}} 59.8,{ }^{2} J\right)$, the oxy-methine $\mathrm{CH}-6\left(\delta_{\mathrm{C}} 73.9,{ }^{3} J\right)$ and the $\mathrm{CH}_{2}-9$ signal $\left(\delta_{\mathrm{C}} 40.3,{ }^{3} J\right)$, respectively.

Table 1. ${ }^{13} \mathrm{C}$ and ${ }^{1} \mathrm{H}$ NMR data of pachydictyols A (3a) and B (1a/1b) in $\mathrm{CDCl}_{3}(J$ in $[\mathrm{Hz}])$.

\begin{tabular}{|c|c|c|c|c|c|c|}
\hline \multirow{2}{*}{ position } & \multicolumn{2}{|c|}{ cis-Pachydictyol B (1a) } & \multicolumn{2}{|r|}{ trans-Pachydictyol B (1b) } & \multicolumn{2}{|c|}{ Pachydictyol A (3a) } \\
\hline & $\boldsymbol{\delta}_{\mathrm{C}}{ }^{(\mathbf{a})}$ & $\delta_{H}^{(b)}$ & $\boldsymbol{\delta}_{\mathrm{C}}{ }^{(\mathbf{a})}$ & $\delta_{H}(c)$ & $\boldsymbol{\delta}_{\mathrm{C}}{ }^{\text {(a) }}$ & $\delta_{H}^{(b)}$ \\
\hline 1 & 46.0 & $2.50(\mathrm{~m})$ & 46.1 & $2.52(\mathrm{~m})$ & 46.1 & $2.67(\mathrm{~m})$ \\
\hline 2 & 33.6 & $2.43(\mathrm{~m}), 2.13(\mathrm{~m})$ & 33.7 & $2.46(\mathrm{~m}), 2.16(\mathrm{~m})$ & 33.9 & $2.50(\mathrm{~m}), 2.22(\mathrm{~m})$ \\
\hline 3 & 123.9 & $5.28(\mathrm{~m})$ & 124.2 & $5.30(\mathrm{~m})$ & 123.9 & $5.33(\mathrm{~m})$ \\
\hline 4 & 140.8 & - & 140.7 & - & 141.3 & - \\
\hline 5 & 59.8 & $2.33(\mathrm{~m})$ & 59.9 & $2.36(\mathrm{~m})$ & 60.4 & $2.30(\mathrm{~m})$ \\
\hline 6 & 73.9 & $4.18(\mathrm{dm}, 7.6)$ & 74.1 & $4.18(\mathrm{~m})$ & 75.1 & $3.92(\mathrm{~d}, 7.8)$ \\
\hline 7 & 48.6 & $1.56(\mathrm{~m})$ & 49.0 & $1.58(\mathrm{~m})$ & 47.8 & $1.55(\mathrm{~m})$ \\
\hline 8 & 21.6 & $1.69(\mathrm{~m})$ & 21.6 & $1.73(\mathrm{~m}), 1.65(\mathrm{~m})$ & 23.6 & $1.50(\mathrm{~m})$ \\
\hline 9 & 40.3 & $2.60(\mathrm{~m}), 2.04(\mathrm{~m})$ & 40.3 & $2.62(\mathrm{dm}, 15.7 \mathrm{~Hz}), 2.06(\mathrm{~m})$ & 40.6 & $2.62(\mathrm{~m}), 2.10(\mathrm{~m})$ \\
\hline 10 & 151.6 & - & 151.5 & - & 152.4 & - \\
\hline 11 & 75.9 & - & 76.0 & - & 34.8 & $1.21(\mathrm{~m})$ \\
\hline 12 & 43.8 & $2.42(\mathrm{~m}), 2.33(\mathrm{~m})$ & 44.0 & $2.47(\mathrm{~m}), 2.37(\mathrm{~m})$ & 35.1 & $2.25(\mathrm{~m}), 1.53(\mathrm{~m})$ \\
\hline 13 & 122.1 & 5.63 (br m) & 126.4 & $5.68(\mathrm{dt}, 15.6,8.0)$ & 25.7 & $2.04(\mathrm{~m}), 1.95(\mathrm{~m})$ \\
\hline
\end{tabular}


Table 1. Cont.

\begin{tabular}{ccccccc}
\hline 14 & 141.6 & $5.64(\mathrm{br} \mathrm{m})$ & 137.4 & $5.60(\mathrm{~d}, 15.6)$ & 124.6 & $5.13(\mathrm{tq}, 8.6,1.3)$ \\
15 & 70.4 & - & 81.6 & - & 131.4 & - \\
16 & 29.4 & $1.24(\mathrm{~s})$ & 24.7 & $1.25(\mathrm{~s})$ & 25.8 & $1.68(\mathrm{~s})$ \\
17 & 15.8 & $1.77(\mathrm{~s})$ & 15.8 & $1.77(\mathrm{~s})$ & 15.9 & $1.81(\mathrm{~d}, 1.3)$ \\
18 & 107.3 & $4.72(\mathrm{br} \mathrm{s}), 4.69(\mathrm{br} \mathrm{s})$ & 107.4 & $4.74(\mathrm{~s}), 4.70(\mathrm{~s})$ & 107.0 & $4.74(\mathrm{br} \mathrm{s})$ \\
19 & 25.4 & $1.15(\mathrm{~s})$ & 25.5 & $1.17(\mathrm{~s})$ & 17.6 & $0.99(\mathrm{~d}, 6.0)$ \\
20 & 29.8 & $1.25(\mathrm{~s})$ & 24.0 & $1.28(\mathrm{~s})$ & 17.7 & $1.61(\mathrm{~s})$ \\
\hline \multicolumn{7}{c}{${ }^{(\mathrm{a})} 125 \mathrm{MHz}{ }^{\left({ }^{b}\right)} 300 \mathrm{MHz}{ }^{(\mathrm{c})} 600 \mathrm{MHz}}$.
\end{tabular}

Table 2. ${ }^{13} \mathrm{C}$ and ${ }^{1} \mathrm{H}$ NMR data of pachydictyol C (2), dictyol C (3b) and dictyol E (4) in $\mathrm{CDCl}_{3}(J$ in $[\mathrm{Hz}])$.

\begin{tabular}{|c|c|c|c|c|c|c|}
\hline \multirow{2}{*}{ position } & \multicolumn{2}{|c|}{ Pachydictyol C (2) } & \multicolumn{2}{|c|}{ Dictyol C (3b) [14] } & \multicolumn{2}{|r|}{ Dictyol E (4) } \\
\hline & $\delta_{C}{ }^{(a)}$ & $\delta_{H}$ & $\boldsymbol{\delta}_{\mathrm{C}}{ }^{(\mathbf{a})}$ & $\delta_{H}{ }^{(b)}$ & $\boldsymbol{\delta}_{\mathrm{C}}{ }^{\text {(a) }}$ & $\delta_{H}$ \\
\hline 1 & 49.1 & $1.25(\mathrm{~m})$ & 49.1 & 2.21 & 46.1 & $2.53(\mathrm{q}, 9.8)$ \\
\hline 2 & 33.0 & $2.21(\mathrm{~m})$ & 32.9 & n.r. & 33.7 & $2.44(\mathrm{~m}), 2.16(\mathrm{~m})$ \\
\hline 3 & 123.2 & $5.26(\mathrm{br} \mathrm{m})$ & 123.4 & $5.26($ br s) & 123.9 & $5.28(\mathrm{br} \mathrm{m})$ \\
\hline 4 & 142.4 & - & 142.5 & - & 140.8 & - \\
\hline 5 & 52.7 & $2.75(\mathrm{~m})$ & 52.7 & $2.74(\mathrm{dd}, 7.8,6.0)$ & 60.0 & $2.34(\mathrm{~m})$ \\
\hline 6 & 74.5 & $3.86(\mathrm{dd}, 8.2,3.4)$ & 74.4 & $3.87(\mathrm{dd}, 7.8,3.6)$ & 74.1 & $4.14(\mathrm{dd}, 7.9,2.7)$ \\
\hline 7 & 50.0 & $2.15(\mathrm{~m})$ & 49.9 & n.r. & 48.3 & $1.60(\mathrm{~m})$ \\
\hline 8 & 19.8 & $1.27(\mathrm{~m}), 1.22(\mathrm{~m})$ & 19.7 & n.r. & 21.5 & $1.71,1.61(2 \mathrm{~m})$ \\
\hline 9 & 34.5 & $1.51(\mathrm{~m})$ & 46.6 & n.r. & 40.4 & $2.63(\mathrm{dm}, 14.5), 2.06(\mathrm{~m})$ \\
\hline 10 & 34.9 & $1.19(\mathrm{~m})$ & 72.4 & - & 151.7 & - \\
\hline 11 & 72.6 & - & 34.4 & n.r. & 76.1 & - \\
\hline 12 & 46.6 & $1.40(\mathrm{~m}), 1.88(\mathrm{~m})$ & 34.7 & n.r. & 40.9 & $1.67(\mathrm{~m})$ \\
\hline 13 & 25.6 & $2.02(\mathrm{~m}), 1.94(\mathrm{~m})$ & 25.5 & n.r. & 23.2 & $1.99(\mathrm{~m})$ \\
\hline 14 & 124.7 & $5.14(\mathrm{~m})$ & 124.7 & $5.14($ br t, 7.1$)$ & 124.2 & $5.10(t, 7.1)$ \\
\hline 15 & 131.3 & - & 131.6 & - & 131.3 & - \\
\hline 16 & 25.8 & $1.68(\mathrm{~s})$ & 25.7 & $1.62(\mathrm{~d}, 0.9)$ & 25.6 & $1.64(\mathrm{~s})$ \\
\hline 17 & 16.3 & $1.82(\mathrm{~s})$ & 16.3 & $1.85(\mathrm{dd}, 2.0,1.2)$ & 15.7 & $1.77(\mathrm{~s})$ \\
\hline 18 & 17.5 & $0.97(\mathrm{~d}, 6.4)$ & 30.0 & $1.22(\mathrm{~s})$ & 107.3 & $4.73(\mathrm{~s}), 4.70($ br d, 1.3$)$ \\
\hline 19 & 30.0 & $1.19(\mathrm{~s})$ & 17.5 & $1.00(\mathrm{~d}, 6.6)$ & 25.1 & $1.18(\mathrm{~s})$ \\
\hline 20 & 17.7 & $1.60(\mathrm{~s})$ & 17.7 & $1.70(\mathrm{~s})$ & 17.6 & $1.57(\mathrm{~s})$ \\
\hline
\end{tabular}

(a) $125 \mathrm{MHz}$; ${ }^{\text {(b) }} 300 \mathrm{MHz}$; n.r., signals not reported.

COSY and HMBC correlations were seen from $\mathrm{CH}_{2}-2\left(\delta_{\mathrm{H}} 2.43,2.13\right)$ to the olefinic methine $\mathrm{CH}-3$ $\left(\delta_{\mathrm{H}} 5.28\right)$ and to $\mathrm{CH}-1\left(\delta_{\mathrm{C}} 46.0\right)$. A ${ }^{3} J_{\mathrm{CH}}$ coupling from the olefinic methyl $\mathrm{CH}_{3}-17\left(\delta_{\mathrm{H}} 1.77\right)$ to $\mathrm{CH}-3$ $\left(\delta_{\mathrm{C}} 123.9\right)$, to $\mathrm{C}_{\mathrm{q}}-4\left(\delta_{\mathrm{C}} 140.8\right)$ and $\mathrm{CH}-5\left(\delta_{\mathrm{C}} 59.8\right)$ completed the methyl-cyclopentene partial structure. The remaining two carbons of the octahydroazulene, $\mathrm{CH}-7\left(\delta_{\mathrm{C}} 48.6, \delta_{\mathrm{H}} 1.56\right)$ and $\mathrm{CH}_{2}-8\left(\delta_{\mathrm{C}} 21.6\right.$, $\delta_{\mathrm{H}}$ 1.69), were assigned through contiguous $\mathrm{H}, \mathrm{H}$ COSY correlations between $\mathrm{CH}_{2}-9\left(\delta_{\mathrm{H}} 2.60,2.04\right)$, $\mathrm{CH}_{2}-8\left(\delta_{\mathrm{H}} 1.69\right), \mathrm{CH}-7\left(\delta_{\mathrm{H}} 1.56\right)$ and $\mathrm{CH}-6\left(\delta_{\mathrm{H}} 4.18\right)$ and confirmed by $\mathrm{H} \rightarrow \mathrm{C}(\mathrm{HMBC})$ correlations (see Figure 2, left). 
Figure 2. Left: H,H COSY (-) and selected HMBC (↔) correlations in cis-pachydictyol B (1a); right: selected NOESY couplings in a preferred conformation of $\mathbf{1 a}$.
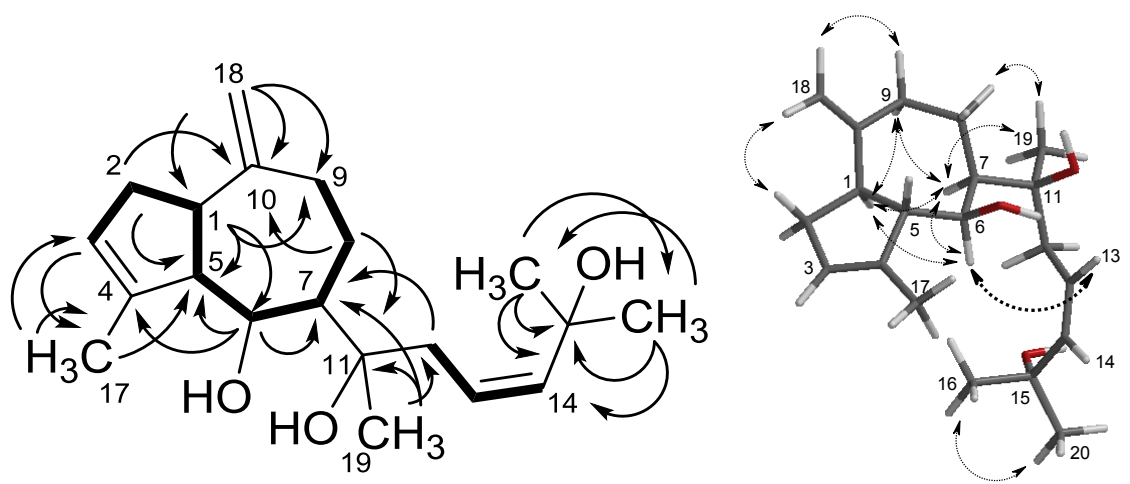

A 1,2-disubstituted ethanediyl $(-\mathrm{CH}=\mathrm{CH}-)$, gem-dimethyls bound to a quaternary oxycarbon $\left[\left(\mathrm{CH}_{3}\right)_{2} \mathrm{C}_{\mathrm{q}}(\mathrm{OH})-\right]$ and a $-\mathrm{C}_{\mathrm{q}}\left(\mathrm{OH}, \mathrm{CH}_{3}\right)-\mathrm{CH}_{2}-$ fragment were identified as sub-structures of the side chain $\mathrm{C}_{8} \mathrm{H}_{15} \mathrm{O}_{2}$ and connected by $\mathrm{HMBC}$ correlations (see Figure 2), resulting in the planar structure, 1a/1b. The high similarity of ${ }^{1} \mathrm{H}$ and ${ }^{13} \mathrm{C}$ NMR shifts of the chiral centers in $\mathbf{1 a}$ and $\mathbf{4}$ (Table 1), as well as NOESY correlations (Figure 2, right), indicated the same relative configuration as found in pachydictyol A (3a) and dictyol E (4): proton H-1 gave NOE signals with $\mathrm{H}-6$ and $\mathrm{H}-7$ and H-7 coupled with H-6 and $H-9 \alpha(\delta 2.04)$, and $H-1$ gave a cross signal with $H-2 \alpha(\delta 2.13)$, indicating a syn-facial orientation of all these hydrogens. This assignment was supported by strong NOE signals between $\delta 2.43(\mathrm{H}-2 \beta)$ and $\delta 4.69(Z-H-18)$ or $\delta 2.60(\mathrm{H}-9 \beta)$ and $\delta 4.72(E-H 18)$, respectively. This agrees very well with semi-empirical calculations [17]. These indicated that in the energy minimum, the exocyclic double bond and the $\mathrm{C} 2_{\beta}$ and $\mathrm{C} 9_{\beta}$ hydrogens are nearly in the same plane and much closer to $\mathrm{CH}_{2}-18$ than the respective $\alpha$-protons. The relative configuration in the ring system of $\mathbf{1 a} / \mathbf{1 b}, \mathbf{3 a}$ and $\mathbf{4}$ is, therefore, certainly the same, and for biosynthetic reasons, the same absolute configuration can also be assumed.

The configuration at C-11 was estimated tentatively on the basis of the expected dominating conformation. By AM1 [17], about 5500 conformers were calculated using the Monte Carlo method, of which $99.3 \%$ in the Boltzmann distribution (19 of 22 molecules in a range of $\sim 15 \mathrm{~kJ} / \mathrm{mol}$ above the global minimum) all showed a hydrogen bridge between the hydroxy groups, 6-OH and 11-OH. Due to the restricted rotation around the $\mathrm{C}-7 / \mathrm{C}-11$ bond resulting thereby, the $(11 S)$ configuration with the 11 -methyl in $\beta$-orientation and an $11 \alpha$ chain (C12-C16) or the corresponding (11R) diastereomer might be differentiated by NOESY data. On this basis, the strong NOE between the double bond protons H-13/14 and both H-6 and H-7 was taken as a clear indication of the (11S) configuration.

In deuteriochloroform at $300 \mathrm{MHz}$, a ${ }^{3} J$ coupling between $\mathrm{H}-13 / 14$ was not visible, due to nearly identical shifts. Inspection of further 1a fractions revealed, however, a second isomer with slightly different ${ }^{1} \mathrm{H}$ and ${ }^{13} \mathrm{C}$ shifts in the region of C-13-C-16/20. In this compound, the olefinic proton, $\mathrm{H}-14$, appeared as a doublet $(J=15.9 \mathrm{~Hz})$, while $\mathrm{H}-13$ gave a doublet of a triplet $(J=15.9,6.4 \mathrm{~Hz})$, clearly indicating an $(E)$-configuration of the side chain (Supplementary Material, Figure S7). As all 2D correlations of both isomers, along with the shifts of the chiral centers, were identical (Figure 2 and Figure S11, Supplementary Material), $\mathbf{1 a}$ and $\mathbf{1 b}$ were determined to be cis- and trans-pachydictyol B, respectively. 
A further diterpene $\mathbf{2}$ was also obtained as a colorless oil. It had similar chromatographic properties as 1a/1b, but a slightly lower polarity. (+)-HRESI MS established the molecular formula as $\mathrm{C}_{20} \mathrm{H}_{34} \mathrm{O}_{2}$, and EI MS delivered fragment ions at $\mathrm{m} / \mathrm{z} 288$ and 270, again due to the successive elimination of two water molecules. In the ${ }^{1} \mathrm{H}$ NMR spectrum, compound 2 displayed the same pattern as dictyol E (4), except that the two exocyclic $\mathrm{sp}^{2}$-methylene signals of $\mathrm{CH}_{2}-18$ in 4 were replaced in 2 by a methyl doublet at $\delta_{\mathrm{H}} 0.97(J=6.4 \mathrm{~Hz})$, with the coupling partner, $\mathrm{H}-10$, giving a multiplet at $\delta_{\mathrm{H}} 1.19$. All other shifts and coupling patterns were similar to those of dictyol E (4) (Table 2). The ${ }^{13} \mathrm{C}$ NMR data were identical, within the limits of error, to those of dictyol C (3b) [14], with the exception of the shifts for C-11/12 and C-18/19 in 2 that were pairwise exchanged against C-10/9 and C-19/18 in 3b (see Table 2 and Figure 3). Accordingly, 2 was confirmed as 5-(1-hydroxy-1,5-dimethylhex-4-enyl)-3, 8-dimethyl-1,3a,4,5,6,7,8,8a-octahydro-azulen-4-ol and named pachydictyol C.

Figure 3. H,H COSY $(-)$ and selected $\operatorname{HMBC~}(\rightarrow)$ couplings in pachydictyol C (2) and dictyol E (4).

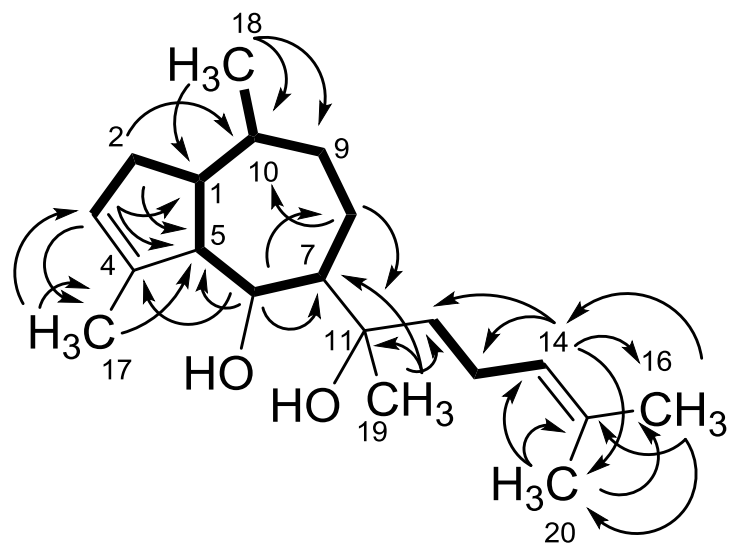

2

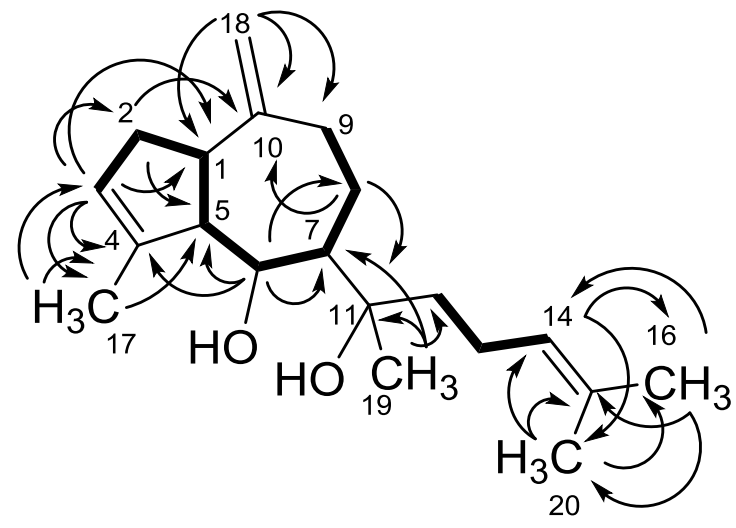

4

In contrast to 1a, 3a and 4, compound 2 showed a negative optical rotation $\left([\alpha]^{20}{ }_{D}=-15^{\circ}\right)$, similar to that of the related 10-methyl derivative dictyol C (3b) $\left([\alpha]^{20}{ }_{D}=-16.6^{\circ}\right)$ [14]. The configuration of 2 was assumed to be the same as in $\mathbf{1}, \mathbf{3 a}$ and $\mathbf{4}$, with regard to the common biosynthetic origin of all dictyols isolated here, because of the closely related shifts of the respective atoms in $\mathbf{3 b}$ and $\mathbf{4}$ and on the basis of similar NOESY correlations (Figure 4). As H-6 showed a strong NOESY correlation with $\mathrm{H}-1$ and a weaker one with $\mathrm{CH}_{3}-18$, an $\alpha$-orientation with an equatorial position of this methyl must be assumed. This is confirmed by a clear correlation of $\mathrm{H}-10$ with $\mathrm{CH}_{2}-13$ and $\mathrm{CH}-14$, which both must be placed on the $\beta$-face, resulting in a $(10 R)$ configuration. Consequently, this compound was assigned as $(1 S, 5 S, 6 S, 7 R, 10 R, 11 S)-2$.

Compound 5a did not absorb UV light as well as the other compounds isolated and gave a pink color with anisaldehyde/sulfuric acid. It was obtained as a nonpolar colorless oil with the molecular formula, $\mathrm{C}_{15} \mathrm{H}_{26} \mathrm{O}$, and identified as cis-africanan-1 $\alpha$-ol, whose structure 5a had been reported previously [16], but was not completely characterized. We report herein the first full NMR assignment of 5a, based on 2D experiments (Table 3, Figure 5). 
Figure 4. Selected NOESY couplings of pachydictyol C (2).

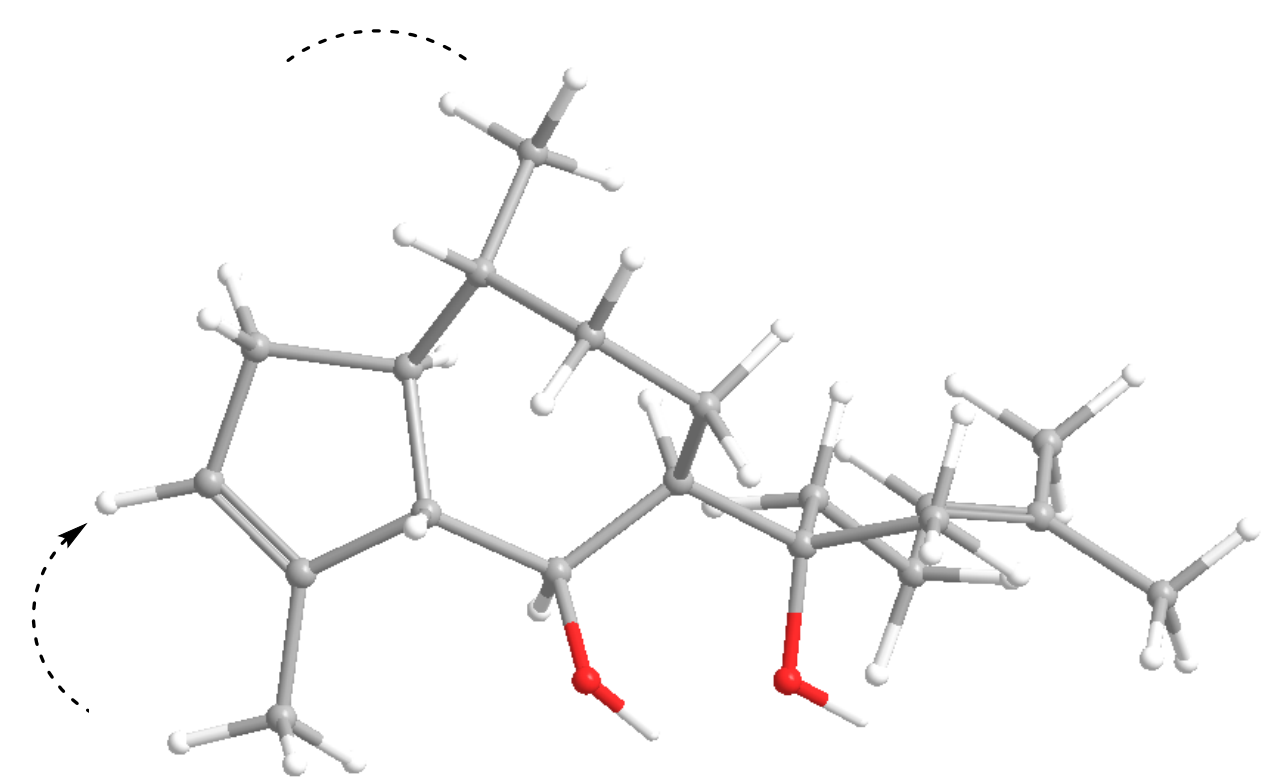

Table 3. ${ }^{13} \mathrm{C}$ and ${ }^{1} \mathrm{H}$ NMR data of $c i s$-africanan- $1 \alpha$-ol (5a) in $\mathrm{CDCl}_{3}(J$ in $[\mathrm{Hz}])$.

\begin{tabular}{|c|c|c|c|c|c|c|}
\hline \multirow{2}{*}{ Position } & \multicolumn{2}{|c|}{ cis-african-1 $\alpha$-ol (5a) Isolated } & \multicolumn{2}{|c|}{ cis-africanan-1 $\alpha-0 l$ (5a) [16] } & \multicolumn{2}{|c|}{ trans-africanan-1 $\alpha-o l(5 b)[18]$} \\
\hline & $\boldsymbol{\delta}_{\mathrm{C}}{ }^{(\mathbf{a})}$ & $\boldsymbol{\delta}_{\mathbf{H}}{ }^{(b)}$ & $\boldsymbol{\delta}_{\mathbf{C}}$ & $\boldsymbol{\delta}_{\mathbf{H}}$ & $\boldsymbol{\delta}_{\mathbf{C}}$ & $\delta_{\mathrm{H}}$ \\
\hline 1 & 83.2 & - & 85.3 & - & 85.9 & - \\
\hline 2 & 41.3 & $1.97(\mathrm{~m}), 1.52(\mathrm{~m})$ & $38.9 *$ & $1.47(\mathrm{~m}), 1.97(\mathrm{~m})$ & 38.1 & $1.88(\mathrm{~m}), 1.92(\mathrm{~m})$ \\
\hline 3 & 32.7 & $1.67(\mathrm{~m}), 1.38(\mathrm{~m})$ & 32.7 & $1.68(\mathrm{~m}), 1.35(\mathrm{~m})$ & 30.1 & $1.96(\mathrm{~m}), 1.17(\mathrm{~m})$ \\
\hline 4 & 43.3 & $1.32(\mathrm{~m})$ & 43.2 & $1.31(\mathrm{~m})$ & 38.1 & $1.74(\mathrm{~m})$ \\
\hline 5 & 55.0 & $1.20(\mathrm{~m})$ & 54.9 & $1.09(\mathrm{~m})$ & 49.5 & $1.05(\mathrm{ddd}, 11.7,10.5,2.7)$ \\
\hline 6 & 41.8 & $1.06(\mathrm{~m}), 1.00(\mathrm{~m})$ & 41.7 & $0.99(\mathrm{~m}), 1.38(\mathrm{~m})$ & 39.8 & $\begin{array}{c}1.19(\mathrm{ddd}, 14.4,2.7,2.1) \\
1.28(\mathrm{dd}, 14.4,11.7)\end{array}$ \\
\hline 7 & 33.3 & - & 33.3 & - & 33.0 & - \\
\hline 8 & 38.9 & $1.04(\mathrm{~m}), 1.49(\mathrm{~m})$ & $41.2 *$ & $1.05,1.47$ & 39.7 & $\begin{array}{c}1.89(\mathrm{dd}, 15.0,11.8), 1.73 \\
(\mathrm{ddd}, 15.0,5.5,2.1)\end{array}$ \\
\hline 9 & 22.3 & $0.81(\mathrm{~m})$ & 22.2 & $0.79(\mathrm{~m})$ & 25.7 & $0.74(\mathrm{~m})$ \\
\hline 10 & 23.6 & - & 23.5 & - & 26.9 & - \\
\hline 11 & 15.3 & $\begin{array}{l}0.66(\mathrm{dd}, 6.4,5.2) \\
0.28(\mathrm{dd}, 8.6,4.1)\end{array}$ & 15.2 & $0.66(\mathrm{~m}), 0.27(\mathrm{~m})$ & 16.3 & $0.74(\mathrm{~m}), 0.31(\mathrm{~m})$ \\
\hline 12 & $26.8 *$ & $1.03 *(\mathrm{~s})$ & 18.9 & $1.03(\mathrm{~s})$ & 23.5 & $1.12(\mathrm{~s})$ \\
\hline 13 & $28.3 *$ & $0.84 *(\mathrm{~s})$ & 29.1 & $0.98(\mathrm{~s})$ & 35.1 & $0.96(\mathrm{~s})$ \\
\hline 14 & $29.2 *$ & $0.98 *(\mathrm{~s})$ & 28.2 & $0.84(\mathrm{~s})$ & 28.0 & $0.94(\mathrm{~s})$ \\
\hline 15 & $18.9 *$ & $1.02 *(\mathrm{~d}, 6.5)$ & 26.7 & $1.02(\mathrm{~d})$ & 19.7 & $0.93(\mathrm{~d}, 6.5)$ \\
\hline
\end{tabular}

(a) $125 \mathrm{MHz}$; ${ }^{\text {(b) }} 300 \mathrm{MHz}$; * differently assigned in the literature. 
Figure 5. H,H COSY $(-, \leftrightarrow)$ and selected HMBC $(\rightarrow)$ couplings of cis-africanan-1 $\alpha$-ol (5a), along with the structure of trans-africanan-1 $\alpha$-ol (5b).

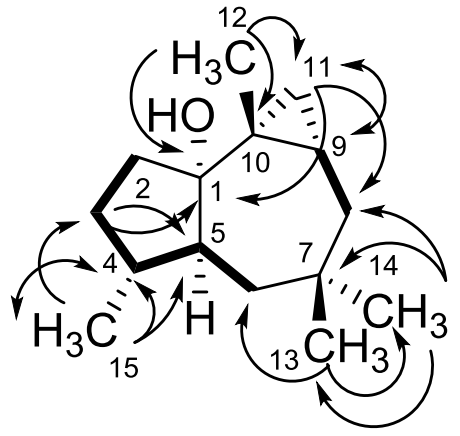

$5 \mathbf{a}$

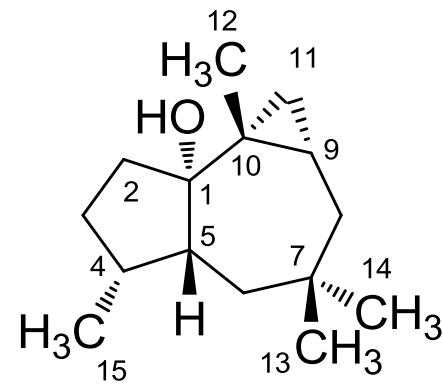

$5 \mathbf{b}$

In addition, tetrahydrothiophene-1,1-dioxide (sulfolan) was isolated from the nonpolar fraction I [19], while fucosterol (6) and poly- $\beta$-hydroxybutyric acid [20,21] were isolated from fraction II. Their structures were confirmed by comparison of their spectroscopic data with that in the literature. Subsequent GC-MS analysis of fraction I and of the unsaponifiable part of a petroleum ether extract of D. dichotoma revealed a further ten (Supplementary Material, Table S1) and eight compounds (Supplementary Material, Table S2), respectively, among them 2,2,6,7-tetramethyl-10-oxatricyclo[4.3.0.1(1,7)]decan-5-one (7), $N$-(4-bromo-n-butyl)-piperidin-2-one (8) and tert-hexadecanethiol (9).

\subsection{Biological Activities}

The crude algal extract showed notable in vitro cytotoxicity against the breast carcinoma tumor cell line, MCF7 $\left(\mathrm{IC}_{50}=0.6 \mu \mathrm{g} \mathrm{mL}{ }^{-1}\right)$, but showed only marginal cytotoxicity against brine shrimp $(3.1 \%$ at $100 \mu \mathrm{g} \mathrm{mL}^{-1}$ ) [22,23]. In the agar diffusion test, extracts of D. dichotoma were not active against bacteria (Bacillus subtilis, Staphylococcus aureus, Streptomyces viridochromogenes (Tü 57), Escherichia coli), fungi (Candida albicans, Mucor miehei, Rhizoctonia solani and Pythium ultimum) [24] or the microalgae, Chlorella vulgaris, C. sorokiniana and Scenedesmus subspicatus, as a test for phytotoxicity, at concentrations of $100 \mu \mathrm{g} /$ disc [25].

(Z)-Pachydictyol B (1a) displayed high antimicrobial activity in the agar diffusion test at $10 \mu \mathrm{g} /$ paper disc against Mucor miehei $(20 \mathrm{~mm})$ and was weakly active against Candida albicans $(11 \mathrm{~mm})$ and Pythium ultimum $(12 \mathrm{~mm})$. Pachydictyol C (2) showed no antimicrobial activity, and both $1 \mathrm{a}$ and 2 were not toxic towards brine shrimp at $10 \mu \mathrm{g} \mathrm{mL} \mathrm{m}^{-1}$. At the time of isolation of pure compounds, the MCF7 test was no longer available and has been substituted by other cell lines (Table 4); the in vitro examination demonstrated weak and unselective cytotoxicity against twelve human tumor cell lines, with a mean $\mathrm{IC}_{50}$ of $>30.0 \mu \mathrm{g} \mathrm{mL}^{-1}$; the high activity of the crude extract could not be reproduced. 
Table 4. Cytotoxic activities of pachydictyols A-C (3a, 1a, 2), Dictyol E (4), cis-africanan-1 $\alpha$-ol (5a) and fucosterol (6).

\begin{tabular}{|c|c|c|c|c|}
\hline \multirow{2}{*}{ Compound } & \multicolumn{2}{|c|}{ Antitumor Potency $^{\text {a }}$} & \multicolumn{2}{|c|}{ Tumor Selectivity $^{b}$} \\
\hline & Mean $\mathrm{IC}_{50}(\mu \mathrm{M})$ & Mean $\mathrm{IC}_{70}(\mu \mathrm{M})$ & $n /$ total & $\%$ \\
\hline cis-pachydictyol B (1a) & $>30.0$ & $>30.0$ & $0 / 12$ & 0 \\
\hline pachydictyol C (2) & $>30.0$ & $>30.0$ & $0 / 12$ & 0 \\
\hline pachydictyol A (3a) & 23.6 & $>30.0$ & $0 / 12$ & 0 \\
\hline dictyol E (4) & $>30.0$ & $>30.0$ & $0 / 12$ & 0 \\
\hline cis-africanan-1 $\alpha-$ ol (5a) & $>10.0$ & $>10.0$ & $0 / 12$ & 0 \\
\hline fucosterol (6) & 19.5 & $>30.0$ & $0 / 12$ & 0 \\
\hline
\end{tabular}

${ }^{\mathrm{a}}$ Mean $\mathrm{IC}_{50 / 70}$ values, determined as the average of 12 human tumor cell lines tested. Individual $\mathrm{IC}_{50}<1 / 2$ mean $\mathrm{IC}_{50}$; e.g., if the mean $\mathrm{IC}_{50}=2.0 \mu \mathrm{M}$, the threshold for the above average sensitivity was $\mathrm{IC}_{50}<1.0 \mu \mathrm{M}$; ${ }^{\mathrm{b}}$ the tumor cell lines are: BXF, bladder; CEXF, cervix; CX,F colorectal; GXF, gastric; LXF, lung; MAXF, breast; MEXF, melanoma xenograft; OVXF, ovarian cancer xenograft; PRXF, prostate; PXF, pleuramesotheliom; $\mathrm{RXF}$, renal; and UXF, uterus body, with $\mathrm{XF}=$ Xenograft Freiburg-derived cell line; A, adeno; L, large cell; E, epidermoid cell; S, small cell.

\section{Experimental Section}

\subsection{General Experimental Procedures}

NMR shifts were referenced on the solvent signal of $\mathrm{CDCl}_{3}\left(\delta_{\mathrm{H}}=7.27, \delta_{\mathrm{C}}=77.0 ; 300\right.$ or $600 \mathrm{MHz}$ for ${ }^{1} \mathrm{H}$ and $125 \mathrm{~Hz}$ for ${ }^{13} \mathrm{C}$ ). GC-MS spectra were measured on a Trace GC-MS Thermo Finnigan chromatograph, using EI ionization mode $(70 \mathrm{eV})$ and a CP-Sil $8 \mathrm{CB}$ capillary column for amines (length: $30 \mathrm{~m}$; inside diameter: $0.25 \mathrm{~mm}$; outside diameter: $0.35 \mathrm{~mm}$; film thickness: $0.25 \mu \mathrm{m}$ ). The analysis was carried out using a temperature program. The initial temperature was $40{ }^{\circ} \mathrm{C}$ (maintained for $1 \mathrm{~min}$ ), and the temperature was then ramped up at a rate of $10{ }^{\circ} \mathrm{C} / \mathrm{min}$ to a final temperature of $280{ }^{\circ} \mathrm{C}$ (kept for $10 \mathrm{~min}$ ). The injector and detector temperature were $250{ }^{\circ} \mathrm{C}$, and $\mathrm{He}$ was used as the carrier gas at a flow rate of $1 \mathrm{~mL} \mathrm{m^{-1 }}$. The total run time was $27 \mathrm{~min}$, and the injection volume was $0.2 \mu \mathrm{L}$. For details see reference [26].

\subsection{Collection and Taxonomy of the Marine Alga}

The brown alga, Dictyota dichotoma (Huds) Lamour, was collected in the summer of 2007 at Ras Abu-Bakr, 65 km north of Ras Gharib on Suez-Gulf, Red Sea, Egypt. The identification was carried out by Abou-ElWafa according to Nasr's method [27,28]. A reference specimen of the alga is kept at the Department of Botany, Faculty of Science, Mansoura University, Egypt.

Samples of Dictyota dichotoma (Huds) Lamour were separated from epiphytes and the dead matrix in running water and rinsed several times in distilled water. The sample was then spread on string nets, allowed to dry in air, ground and stored in closed bottles at room temperature.

\subsection{Extraction and Isolation of the Bioactive Constituents}

The air-dried algal material ( 360 g) was extracted in a Soxhlet apparatus for $\sim 12 \mathrm{~h}$ using dichloromethane (DCM). The DCM extract was filtered and the solvent evaporated in vacuo at $40{ }^{\circ} \mathrm{C}$, 
affording $14.3 \mathrm{~g}$ of a greenish brown crude extract. This extract was fractionated on a silica gel column, eluting with petroleum ether (boiling range $40-60{ }^{\circ} \mathrm{C}$ )-DCM and $\mathrm{DCM}-\mathrm{MeOH}$ gradients, delivering five fractions: I (0.11 g), II (3.2 g), III (2.3 g), IV (2.6 g) and V (5.1 g). TLC monitoring was used, with anisaldehyde/sulfuric acid as the spraying reagent. The first nonpolar fraction I was submitted to GC-MS analysis, detecting the existence of tetrahydrothiophen-1,1-dioxide, $\beta$-bourbonene and nine further compounds (Supplementary Material, Table S1). A preparative separation of fraction I on silica gel (eluting with a cyclohexane-DCM gradient) afforded a pale yellow oil, which was further purified on Sephadex LH-20 (DCM/40\% MeOH) to give the colorless, oily, tetrahydrothiophene-1,1-dioxide (9 $\mathrm{mg}, 0.06 \%$ ). Fraction II was applied to a Sephadex LH-20 (DCM/40\% MeOH) to afford two sub-fractions, IIa $(0.7 \mathrm{~g})$ and IIb (2.4 g). Sub-fraction IIa was not further investigated. Sub-fraction IIb (2.4 g) was washed with methanol to give the insoluble, colorless solid, poly- $\beta$-hydroxybutyric acid $(1.47 \mathrm{~g}, 10.3 \%)$. The soluble part of the methanolic extract $(0.88 \mathrm{~g})$ was applied to a silica gel column and eluted with a cyclohexane/DCM gradient to deliver pachydictyol A (3a) (18.2 mg, 0.12\%) and cis-africanan-1 $\alpha$-ol (5a) (13.1 mg, 0.09\%) as colorless oils. Further purification of sub-fraction IIb afforded fucosterol $(6,30.2 \mathrm{mg}, 0.21 \%)$ as a colorless solid. The eluates from fractions III and IV were combined (4.9 g) and purified on a Sephadex LH-20 column $(\mathrm{MeOH})$ to give sub-fraction IIIa $(2.5 \mathrm{~g})$. The latter was further purified by silica gel column chromatography, eluting with DCM-MeOH gradients, to afford the colorless oily compound, dictyol E $(4,55.0 \mathrm{mg}, 0.38 \%)$. The last polar fraction $\mathrm{V}$ was separated by column chromatography on silica gel, again eluting with DCM-MeOH gradients, to give sub-fractions $\mathrm{Va}(1.2 \mathrm{~g})$ and $\mathrm{Vb}(50.2 \mathrm{mg})$. Sub-fraction $\mathrm{Va}$ was purified by PTLC (DCM) and a subsequent silica gel column (cyclohexane-DCM) to yield pachydictyol C (2, $8.0 \mathrm{mg}, 0.06 \%)$ as a colorless oil. Finally, purification of sub-fraction $\mathrm{Vb}$ on silica gel (DCM-MeOH) afforded $(Z)$-pachydictyol B (1a, $30.0 \mathrm{mg}, 0.21 \%)$ and (E)-pachydictyol B (1b, $13 \mathrm{mg}, 0.09 \%)$ as colorless oils.

Tetrahydrothiophene-1,1-dioxide: Colorless oil, UV non-absorbing, turned brown on spraying with anisaldehyde/sulfuric acid or by $\mathrm{PdCl}_{2}(0.5 \%$ in water $)$ and heating; $R_{\mathrm{f}}=0.68\left(\mathrm{CH}_{2} \mathrm{Cl}_{2} / 5 \% \mathrm{MeOH}\right)$; ${ }^{1} \mathrm{H}$ NMR data $\left(300 \mathrm{MHz}\right.$, in $\left.\mathrm{CDCl}_{3}\right): \delta=3.05(\mathrm{~m}, 4 \mathrm{H}), 2.22(\mathrm{~m}, 4 \mathrm{H}) ;{ }^{13} \mathrm{C}$ NMR data $(75 \mathrm{MHz}$, in $\left.\mathrm{CDCl}_{3}\right): \delta=50.9\left(2 \mathrm{CH}_{2}\right), 22.5\left(2 \mathrm{CH}_{2}\right)$; EI-MS $(70 \mathrm{eV}): \mathrm{m} / z(\%)=122\left({ }^{34} \mathrm{~S}[\mathrm{M}]^{+\bullet}, 2\right), 120\left({ }^{32} \mathrm{~S}[\mathrm{M}]^{+\bullet}\right.$, 44), $56\left(\left[\mathrm{M}-\mathrm{SO}_{2}\right]^{+\bullet}, 96\right), 55\left(\left[\mathrm{M}-\mathrm{HSO}_{2}\right]^{+}, 72\right), 48$ (6), 41 (100); HREI-MS: $m / z=120.0245$ (calcd. 120.0245 for $\left.\mathrm{C}_{4} \mathrm{H}_{8} \mathrm{O}_{2} \mathrm{~S}\right)$.

cis-Pachydictyol B (1a): Colorless oil, UV non-absorbing, turned dark violet on spraying with anisaldehyde/sulfuric acid and heating; $R_{\mathrm{f}}=0.40\left(\mathrm{CH}_{2} \mathrm{Cl}_{2} / 3 \% \mathrm{MeOH}\right), 0.35$ (cyclohexane $/ 50 \%$ $\left.\mathrm{CH}_{2} \mathrm{Cl}\right) ;[\alpha]^{20}{ }_{\mathrm{D}}+7(c=0.1, \mathrm{MeOH}) ;{ }^{1} \mathrm{H} \mathrm{NMR}\left(300 \mathrm{MHz}\right.$, in $\left.\mathrm{CDCl}_{3}\right)$ and ${ }^{13} \mathrm{C} \mathrm{NMR}(150 \mathrm{MHz}$, in $\left.\mathrm{CDCl}_{3}\right)$, see Table 1; EI-MS $(70 \mathrm{eV}): m / z(\%)=302\left(\left[\mathrm{M}-\mathrm{H}_{2} \mathrm{O}\right]^{+\bullet}, 6\right), 284\left(\left[\mathrm{M}-2 \mathrm{H}_{2} \mathrm{O}\right]^{+\bullet}, 12\right), 241$ (4), 221 (22), 203 (14), 175 (10), 159 (48), 145 (35), 133 (24), 107 (20), 105 (22), 82 (62), 71 (18), 55 (14), 43 (100), 41 (25); (+)-DCI-MS: $m / z(\%)=338\left(\left[\mathrm{M}+\mathrm{NH}_{4}\right]^{+}, 100\right), 320\left(\left[\mathrm{M}+\mathrm{NH}_{4}-\mathrm{H}_{2} \mathrm{O}\right]^{+}, 76\right)$; $(+)$-HRESI-MS: $m / z=343.22437[\mathrm{M}+\mathrm{Na}]^{+}\left(\right.$calcd. 343.22436 for $\mathrm{C}_{20} \mathrm{H}_{32} \mathrm{O}_{3} \mathrm{Na}$ ).

trans-Pachydictyol B (1b): The trans isomer was obtained as a colorless oil with similar chromatographic properties and mass spectra as found for 1a, but with a slightly lower polarity $\left(R_{\mathrm{f}}=0.45\left(\mathrm{CH}_{2} \mathrm{Cl}_{2} / 3 \% \mathrm{MeOH}\right) ; \mathrm{NMR}\right.$ data, see Table 1 . 
Pachydictyol C (2): Colorless oil, UV non-absorbing, turned dark violet on spraying with anisaldehyde/sulfuric acid and heating; $R_{\mathrm{f}}=0.55$ (cyclohexane $\left./ 50 \% \mathrm{CH}_{2} \mathrm{Cl}_{2}\right) ;[\alpha]^{20}{ }_{\mathrm{D}}-15(c=0.1$, $\mathrm{MeOH}) ;{ }^{1} \mathrm{H}$ NMR $\left(300 \mathrm{MHz}\right.$, in $\left.\mathrm{CDCl}_{3}\right),{ }^{13} \mathrm{C} \mathrm{NMR}\left(150 \mathrm{MHz}\right.$, in $\mathrm{CDCl}_{3}$ ) see Table 2; EI-MS (70 eV): $m / z(\%)=306\left([\mathrm{M}]^{+}, 8\right), 288\left(\left[\mathrm{M}-\mathrm{H}_{2} \mathrm{O}\right]^{+\bullet}, 84\right), 270\left(\left[\mathrm{M}-2 \mathrm{H}_{2} \mathrm{O}\right]^{+\bullet}, 10\right), 245(6), 213(8), 203$ (18), 185 (24), 177 (52), 159 (64), 133 (26), 121 (39), 119 (56), 93 (30), 81 (49), 69 (78), 55 (67), 43 (100); $(+)$-HRESI-MS: $m / z=329.24510[\mathrm{M}+\mathrm{Na}]^{+}$(calcd. 329.24510 for $\mathrm{C}_{20} \mathrm{H}_{34} \mathrm{O}_{2} \mathrm{Na}$ ).

cis-Africanan-1- $\alpha$-ol (5a): Colorless oil, UV non-absorbing, turned pink on spraying with anisaldehyde/sulfuric acid and heating; $R_{\mathrm{f}}=0.88$ (cyclohexane $\left./ 50 \% \mathrm{CH}_{2} \mathrm{Cl}_{2}\right) ;[\alpha]_{\mathrm{D}}^{20}+7(c=0.2$, $\mathrm{MeOH}) ;{ }^{1} \mathrm{H}$ NMR $\left(300 \mathrm{MHz}\right.$, in $\left.\mathrm{CDCl}_{3}\right),{ }^{13} \mathrm{C} \mathrm{NMR}\left(150 \mathrm{MHz}\right.$, in $\mathrm{CDCl}_{3}$ ) see Table 3; EI-MS (70 eV): $m / z(\%)=222\left([\mathrm{M}]^{+}, 8\right), 207\left(\left[\mathrm{M}-\mathrm{CH}_{3}\right]^{+}, 16\right), 175$ (12), 159 (34), 125 (58), 95 (38), 81 (46), 69 (88), 41 (100); DCI-MS: $m / z(\%)=222\left(\left[\mathrm{M}+\mathrm{NH}_{4}-\mathrm{H}_{2} \mathrm{O}\right]^{+}, 25\right), 205\left(\left[\mathrm{M}-\mathrm{H}_{2} \mathrm{O}\right]^{+}, 100\right)$; (+)-HRESI-MS: $m / z=245.18773[\mathrm{M}+\mathrm{Na}]^{+}$(calcd. 245.18766 for $\mathrm{C}_{15} \mathrm{H}_{26} \mathrm{ONa}$ ).

\subsection{Estimation of Phytosterols and Hydrocarbons}

A powdered sample $(10 \mathrm{~g})$ of Dictyota dichotoma was extracted with petroleum ether $\left(60-80{ }^{\circ} \mathrm{C}\right)$ at room temperature and concentrated in vacuo to give an oily residue $(70 \mathrm{mg})$. This extract was then treated with $50 \mathrm{~mL}$ of $10 \%$ alcoholic $\mathrm{KOH}$ and refluxed in a water bath for $2 \mathrm{~h}$. After cooling, $50 \mathrm{~mL}$ of water was added, and the solution was extracted with chloroform. The organic phase was washed with water until it became alkali free and was then dried over anhydrous $\mathrm{Na}_{2} \mathrm{SO}_{4}$. The solvent was evaporated to give the unsaponified fraction as oil, which was subsequently subjected to GC-MS analysis [29] (Supplementary Material, Table S2).

\subsection{Biological Activity Study}

Antimicrobial activity was determined according to Burkholder et al. [24]. The Brine Shrimp Microwell Cytotoxic Assay was performed according to Takahashi et al. and Sajid et al. [22,23]. The in vitro cytotoxicity test was carried out using the sulforhodamine B SRB assay according to Skehan et al. [30].

The antitumor activity testing was performed as follows: A modified propidium iodide assay was used to examine the antiproliferative activity of the compounds against human tumor cell lines. The test procedure has been described elsewhere [31]. Cell lines tested were derived from patient tumors engrafted as a subcutaneously growing tumor in NMRI nu/nu mice or obtained from American Type Culture Collection, Rockville, MD, National Cancer Institute, Bethesda, MD, or Deutsche Sammlung von Mikroorganismen und Zellkulturen, Braunschweig, Germany.

\section{Conclusions}

Three new pachydictyols, namely $(Z)$ - and $(E)$-pachydictyols $\mathrm{B}(\mathbf{1 a} / \mathbf{1 b})$ and $\mathrm{C}(\mathbf{2})$, along with the known pachydictyol A (3a), dictyol E (4), cis-africanan-1 $\alpha$-ol (5a), fucosterol (6), tetrahydrothiophene-1,1-dioxide and poly- $\beta$-hydroxybutyric acid, were isolated from the marine brown alga, Dictyota dichotoma. GC-MS analysis of the nonpolar fractions of the algal extract revealed the presence of ten further compounds, whilst the same analysis of the unsaponified petroleum ether 
extract of the algae detected a further eight compounds (Supplementary Material, Tables S1 and S2). The chemical structures of compounds 1-6 were assigned by 1D and 2D NMR spectroscopy, mass spectrometry (EI, CI, HREI, HRESI) and by comparison of the data with that of related structures. The algal extract exhibited no antimicrobial activity against a diverse range of microorganisms and no cytotoxicity against brine shrimp. In contrast to the high anticancer activity of the crude extract against the breast carcinoma tumor cell line, MCF7 $\left(\mathrm{IC}_{50}=0.6 \mu \mathrm{g} \mathrm{mL}{ }^{-1}\right)$, the purified components were only weakly active (Table 4).

\section{Acknowledgments}

The authors are thankful to H. Frauendorf and R. Machinek for MS and NMR measurements. We also thank F. Lissy for biological activity tests, A. Kohl for technical assistance and Sarah Hickford for careful language polishing. M. S. thanks the German Academic Exchange Service (DAAD) for a short-term grant.

\section{Conflicts of Interest}

The authors declare no conflict of interest.

\section{References}

1. Vashishta, B.R. Botany for Degree Students, Part 1, Algae, 7th ed.; S. Chand \& Company Ltd.: New Delhi, India, 1984; p. 5.

2. Duran, R.; Zubia, E.; Ortega, M.J.; Salva, J. New diterpenoids from the alga Dictyota dichotoma. Tetrahedron 1997, 53, 8675-8688.

3. Gedaraa, S.R.; Abdel-Halim, O.B.; El-Sharkawya, S.H.; Salama, O.M.; Shier, T.W.; Halim, A.F. Cytotoxic hydroazulene diterpenes from the brown alga Dictyota dichotoma. Z. Naturforsch. 2003, 58b, 17-22.

4. Freitas, O.S.P.; Santos de Oliveira, A.; de-Paula, J.C.; Pereira, R.C.; Cavalcanti, D.N.; Teixeira, V.L. Chemical variation in the diterpenes from the Brazilian brown alga Dictyota mertensii (Dictyotaceae, Phaeophyta). Nat. Prod. Commun. 2007, 2, 13-15.

5. Teixeira, V.L.; Almeida, S.A.; Kelecom, A. Chemsystematic and biogeographic studies of the diterpenes. Biochem. Syst. Ecol. 1990, 18, 87-92.

6. De-Paula, J.C.; Bueno, L.B.; Cavalcanti, D.N.; Yoneshigue-Valentin, Y.; Teixeira, V.L. Diterpenes from the brown alga Dictyota crenulata. Molecules 2008, 13, 1253-1262.

7. Suzuki, M.; Yamada, H.; Kurata, K. Dictyterpenoids A and B, two novel diterpenoids with feeding-deterrent activity from the brown alga Dilophus okamurai. J. Nat. Prod. 2002, 65, 121-125.

8. Schmitt, T.M.; Lindquist, N.; Hay, M.E. Seaweed secondary metabolites as antifoulants. Effects of Dictyota spp. diterpenes on survivorship, settlement, and development of marine invertebrate larvae. Chemoecology 1998, 8, 125-131.

9. Soto, R.H.; Rovirosa, R.J.; San Martin, A.; Argandona, V. Secondary metabolites of Dictyota crenulata. Bol. Soc. Chil. Quim. 1994, 39, 173-178. 
10. Patil, A.D.; Berry, D.; Brooks, D.P.; Hemling, M.E.; Kumar, N.V.; Mitchell, M.P.; Ohlstein, E.H.; Westley, J.W. A diterpene epoxide from the marine brown alga Dictyota sp.: Possible vasopressin V1 receptor antagonist. Phytochemistry 1993, 33, 1061-1064.

11. Cavalcanti, D.N.; Rezende, C.M.; Pinto, A.C.; Teixeira, V.L. Diterpenoid constituents from the brown alga Dictyota menstrualis (Dictyotaceae, Phaeophyta). Nat. Prod. Commun. 2006, 1, 609-611.

12. Teixeira, V.L.; Cavalcanti, D.N.; Pereira, R.C. Chemotaxonomic study of the diterpenes from the brown alga Dictyota menstrualis. Biochem. Syst. Ecol. 2001, 29, 313-316.

13. Pereira, R.C.; Teixeira, V.L.; Kelecom, A. Chemical defenses against herbivores in marine algae. 1. The brown alga Dictyota dichotoma (Hudson) Lamouroux from Brazil. An. Acad. Bras. Cienc. 1994, 66, 229-235.

14. Danise, B.; Minale, L.; Riccio, R.; Amico, V.; Oriente, G.; Piattelli, M.; Tringali, C.; Fattorusso, E.; Magno, S.; Mayol, L. Further perhydroazulene diterpenes from marine organisms. Experientia 1977, 33, 413-415.

15. Ovenden, S.P.B.; Nielson, J.L.; Liptrot, C.H.; Willis, R.H.; Tapiolas, D.M.; Wright, A.D.; Motti, C.A. Update of spectroscopic data for 4-hydroxydictyolactone and dictyol E isolated from a Halimeda stuposa-Dictyota sp. Assemblage. Molecules 2012, 17, 2929-2938.

16. Fricke, C. Terpenoide Inhaltsstoffe von Lebermosen und Heilpflanzen. Ph.D. Thesis, University Hamburg, Germany, 1999. Available online: http:/www.sub.uni-hamburg.de/opus/volltexte/ 1999/189/ (accessed on 22 September 2012).

17. SPARTAN'08; Wavefunction, Inc.: Irvine, CA, USA, 2009.

18. Del Coronel, A.; Cerda-García-Rojas, C.M.; Joseph-Nathan, P.; Catalán, C.A.N. Chemical composition, seasonal variation and a new sesquiterpene alcohol from the essential oil of Lippia integrifolia. Flavour Fragr. J. 2006, 21, 839-847.

19. Abou-ElWafa, G.S.E.; Shaaban, M.; Shaaban, K.A.; El-Naggar, M.E.E.; Laatsch, H. Three new unsaturated fatty acids from the marine green alga Ulva fasciata Delile. Z. Naturforsch. 2009, 64b, 1199-1207.

20. Maskey, R.P.; Kock, I.; Shaaban, M.; Grün-Wollny, I.; Helmke, E.; Mayer, F.; Wagner-Döbler, I.; Laatsch, H. Low molecular weight oligo- $\beta$-hydroxybutyric acids and 3-hydroxy- $N$-phenethylbutyramide new products from microorganisms. Polym. Bull. 2002, 49, 87-93.

21. Anderson, A.J.; Dawes, E.A. Occurrence, metabolism, metabolic role, and industrial uses of bacterial polyhydroxyalkanoates. Microbiol. Rev. 1990, 54, 450-472.

22. Takahashi, A.; Kurasawa, S.; Ikeda, D.; Okami, Y.; Takeuchi, T. Altemicidin, a new acaricidal and antitumor substance. I. Taxonomy, fermentation, isolation and physico-chemical and biological properties. J. Antibiot. 1989, 32, 1556-1561.

23. Sajid, I.; Fondja Yao, C.B.; Shaaban, K.A.; Hasnain, S.; Laatsch, H. Antifungal and antibacterial activities of indigenous Streptomyces isolates from saline farmlands: Prescreening, ribotyping and metabolic diversity. World J. Microbiol. Biotechnol. 2009, 25, 601-610.

24. Burkholder, P.R.; Burkholder, L.M.; Almodovar, L.R. Antibiotic activity of some marine algae of Puerto Rico. Bot. Mar. 1960, 2, 149-156. 
25. Biabani, M.A.F.; Baake, M.; Lovisetto, B.; Laatsch, H.; Helmke, E.; Weyland, H. Anthranilamides: New antimicroalgal active substance from a marine Streptomyces sp. J. Antibiot. 1998, 51, 333-340.

26. Zinad, D.S.; Shaaban, K.A.; Abdalla, M.A.; Islam, T.; Schüffler, A.; Laatsch, H. Bioactive isocoumarins from a terrestrial Streptomyces sp. ANK302. Nat. Prod. Commun. 2011, 6, 45-48.

27. Nasr, A.H. The Marine Algae of Alexandria. 1-A Report on Some Marine Algae Collected from the Vicinity of Alexandria; Notes and Memoirs No. 36; Government Press: Cairo, Egypt, 1940; p. 33.

28. Abou-El Wafa, G.S.E.; El-Naggar, M.E.E. Studies on the biological activities of some species of Egyptian marine algae. Personal communication, 2005.

29. Abou-El Wafa, G.S.E. Comparative Studies on Biogenic Compounds in Some Species of Egyptian Marine Algae. Ph.D. Thesis, El-Mansoura University, Egypt, 2011.

30. Skehan, P.; Storeng, R.; Scudiero, D.; Monks, A.; McMahon, J.; Vistica, D.; Warren, J.T.; Bokesch, H.; Kenney, S.; Boyd, M.R. New colorimetric cytotoxicity assay for anticancer-drug screening. J. Natl. Cancer Inst. 1990, 82, 1107-1112.

31. Dengler, W.A.; Schulte, J.; Berger, D.P.; Mertelsmann, R.; Fiebig, H.H. Development of a propidium iodide fluorescence assay for proliferation and cytotoxicity assays. Anticancer Drugs 1995, 6, 522-532.

(C) 2013 by the authors; licensee MDPI, Basel, Switzerland. This article is an open access article distributed under the terms and conditions of the Creative Commons Attribution license (http://creativecommons.org/licenses/by/3.0/). 